УДК 372.881.116.12:004

Шепетко Юлія Миколаївна, аспірант Луганського національного університету імені Тараса Шевченка, м. Луганськ

\title{
ЕЛЕКТРОННИЙ ПІДРУЧНИК ЯК ЕФЕКТИВНИЙ ЗАСІБ ПІДВИЩЕННЯ ЯКОСТІ ОСВІТИ
}

\begin{abstract}
Анотація
Актуальність матеріалу, викладеного у статті, обумовлена потребами у використанні інформаційно-комунікаційних технологій у навчальному процесі, зокрема електронного підручника, який покликаний полегшити сприйняття інформації, урізноманітнити форми роботи, зацікавити технічними можливостями. Мета статті полягає в доведенні необхідності використання електронного підручника як ефективного засобу підвищення якості освіти. Використання електронного підручника під час навчання ефективно і позитивно впливатиме на процес підготовки студентів 3 урахуванням засобів організації навчального процесу, структури, методологічних вимог. Застосування електронного підручника під час навчання сприятиме подальшому розвитку пізнавальної мотивації студентів.

Ключові слова: електронний підручник, комп’ютерні технології, інтерактивний метод.

Постановка проблеми. Сучасний напрямок розвитку людини характеризується впровадженням комп'ютерних технологій у сфері освіти. В освітньому процесі комп'ютер є потужним засобом навчання і виховання. Б. С. Гершунський уважав, що «...комп’ютери дозволяють досягти більш високого рівня наочності запропонованого матеріалу, значно розширюють можливості впровадження різноманітних вправ у процесі навчання, а безперервний зворотний зв'язок, підкріплений ретельно обміркованими стимулами навчання, живить навчальний процес, сприяє підвищенню його динамізму» [1, с. 162].

Використання комп'ютерів у навчальних закладах, зокрема коледжах, для вивчення різних дисциплін дозволить підвищити результативність навчання, але за умови підвищення ефективності якості освіти. Освіта є важливою, невід'ємною сферою соціального життя. Саме освіта формує інтелектуальну, духовну, культурну,
\end{abstract}


спроможну до дій особистість, необхідну сучасному суспільству. Завдання, яке стоїть перед викладачами коледжів - покращити якість освіти майбутніх спеціалістів шляхом урізноманітнення форм i методів навчання. Якість освіти полягає в необхідності отримання знань у конкретних умовах, тобто їх отримання i використання в процесі навчання й під час виробничої практики. Якісна підготовка майбутніх фахівців залежить не тільки від викладача будь-якої дисципліни, від подання ним навчальної інформації, але й від бажання студента вчитися, пізнавати нове, розвивати уявне, творче мислення за допомогою відбору потрібної навчальної інформації шляхом іiї експериментування та за рахунок власних пропозицій, пошукової роботи, пов'язаної 3 аналізом отриманої інформації, розуміння взаємозв’язку між реальними фактами та уявними подіями. Але, щоб надати студентам можливість експериментувати, розвивати інтуїтивне, творче, образне мислення, треба використовувати нові засоби навчання, одним 3 яких є електронний підручник. Тому перед нами постало завдання: розробити і запровадити в навчальний процес електронний підручник з української мови (за професійним спрямуванням), мета якого полягає в зацікавленні студентів компактним викладенням навчальної інформації, цікавими практичними завданнями, розрахованими на вдосконалення набутих умінь і навичок; у вихованні творчої самореалізації та самовдосконаленні особистості шляхом індивідуалізації навчання, вільним вибором темпу роботи, місця роботи, часу роботи. Ми переконані, зважаючи на мету електронного підручника, що зацікавленість студентів у роботі з електронним підручником з української мови (за професійним спрямуванням) зросте, тим самим підвищить якість знань студентів, які визначатимуться, сподіваємось, фундаментальністю і глибиною. Перевірити якість отриманих знань з дисципліни можна вже буде під час виробничої практики, що дозволить говорити про студента як фахівця, конкурентоспроможну особистість, яка буде затребувана роботодавцями після закінчення навчання.

Аналіз досліджень і публікацій. Педагоги та психологи (Роджер Д. Вільямс, В. М. Глушков, В .В. Лапінський, М. І. Жалдак, Н. В. Морзе, В. В. Вембер, Ю. І. Машбиць, Н. Ф. Тализіна, Ю. Б. Максименко) впевнені, що використання засобів інформаційних технологій, зокрема електронного підручника, під час навчання є одним із шляхів реалізації професійних якостей викладача і підвищення інтенсивного, ефективного, індивідуального навчального процесу за умов їх 
комплексного, доцільного використання. Вони довели, що інтегрування традиційного заняття з використанням комп'ютера може зробити процес навчання більш цікавим, креативним, різноманітним, а великий обсяг інформації - доступний для сприйняття та швидкого запам'ятовування.

Мета статті - довести ефективність електронного підручника як засобу підвищення якості освіти.

Виклад основного матеріалу. Електронний підручник - це сучасний засіб навчання, який значною мірою підвищує якість навчання, розвиває творчі здібності, інтуїтивне, образне мислення, сприяє вдосконаленню самостійних умінь і навичок, задовольняє з точки зору раціональної економії часу. Використання електронного підручника дозволить оптимізувати роботу викладача i покращити мотивацію студентів.

Наголосимо, що електронний підручник не покликаний замінити друкований підручник, а спроможний полегшити процес опрацювання теоретичного матеріалу i виконання практичних завдань, оскільки використовується паралельно $з$ традиційним підручником. В. П. Вембер пише, що електронний підручник може доповнити традиційний підручник за рахунок подання навчального матеріалу в іншому вигляді за допомогою акцентів на ключових поняттях, тез та опорних схем, використання інтерактивних завдань, великої кількості мультимедійного ілюстративного матеріалу, що може використовуватися як у фронтальній роботі 3 використанням мультимедійного проектора та інтерактивної дошки, так і для самостійної роботи 3 навчальним матеріалом, узагальнення, повторення тощо; а також додаткових матеріалів, файлів-заготовок і шаблонів для виконання практичних завдань [2, с. 44].

Текст - основне навантаження традиційного друкованого підручника, який, безперечно, насичений ілюстраціями, схемами, таблицями тощо. В електронному підручнику вміщено не тільки ілюстративний матеріал, а й відеоматеріали. «Засоби мультимедіа дозволяють подати навчальний матеріал у захоплюючій, динамічній формі, а інженерні конструкції, пристрої, елементи — як рухомі тривимірні об'єкти, тим самим повною мірою розкриваючи їх конструкцію і принцип дії» [3, с. 20]. Працювати з підручниками можна в будь-який час, але тільки електронний підручник має функцію викладача, репетитора, аналізатора, контролера, співрозмовника. Учень 
або студент під час виконання домашнього завдання або під час опрацювання самостійно навчального матеріалу може:

- виконати практичне завдання й тимчасово отримати результат;

- виконати творче завдання, розраховане на розвиток логічного мислення, умінь і навичок, на вдосконалення власного мовлення, на здатність володіти словом, і відправити це завдання електронною поштою викладачеві.

Покажемо графічно модель використання традиційного друкованого та електронного підручників (рис. 1, 2).

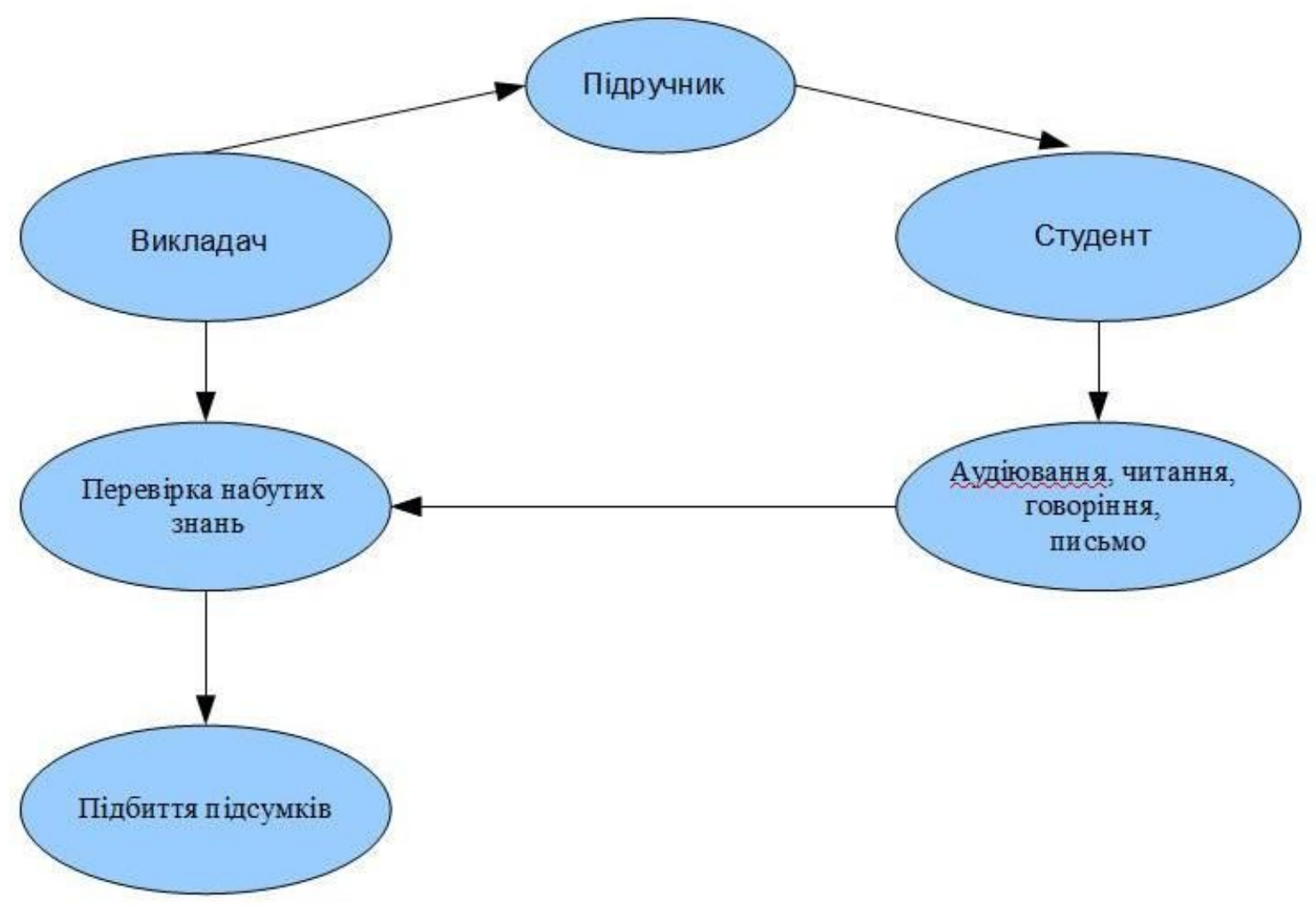

Рис. 1. Модель використання традиційного друкованого підручника 


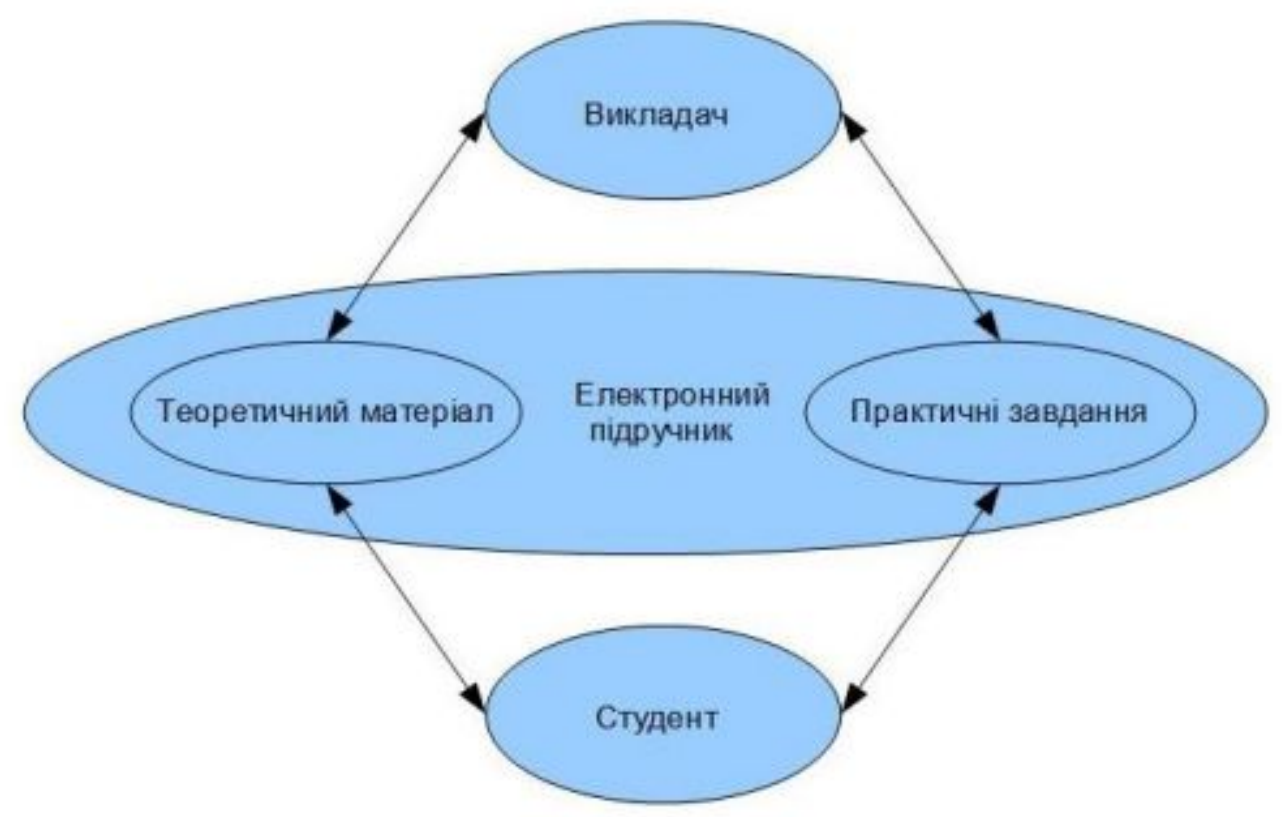

Рис. 2. Модель використання електронного підручника

Робота 3 друкованим підручником - це метод навчання, який полягає в опрацюванні кожного структурного компоненту книги як під керівництвом викладача, так і за самостійного опрацюванні матеріалу, унаслідок чого студенти засвоюють навчальну інформацію. Робота «з друкованими виданнями взагалі $\epsilon$ елементом всесвітньої культури людства, має свої гносеологічні корені, органічно відповідає антропології освіти» [4, с. 161].

Робота з електронним підручником (далі ЕП), можна сказати, дублює роботу, яка проходить 3 використанням друкованого підручника, студентові точно так необхідна допомога викладача, допомога додаткової літератури. Але ЕП розроблений так, що майже вся потрібна інформація знаходиться в межах підручника. Виконання більшості практичних завдань передбачає моментальне оцінювання, що дає змогу студентові самостійно виконувати й оцінювати свої знання; можливість повторного виконання завдання для покращення результатів спонукає студента до повторення теоретичного матеріалу, і він охоче повторюватиме, бо вже зацікавлений швидким оцінюванням. I ще один незаперечний факт: у студентів з'являється бажання конкурувати між собою, вихваляючись своїми позитивними результатами один перед одним, що позитивно впливатиме на вдосконалення працездатності, на подолання неграмотності, на впевненість у своїх силах.

Можливості ЕП полягають у: 
- збереженні великого обсягу інформації, що дає змогу не відриваючись працювати $з$ навчальним матеріалом;

- швидкому пошуку потрібного розділу, теми, словника; слова, словосполучення, речення, що здійснюється за допомогою функції швидкого пошуку;

- мультимедійності, під якою розуміємо одночасне використання різних форм надання інформації та іiі опрацювання; можливості самоконтролю, оскільки ЕП дає змогу перевірити рівень знань, сформованих умінь і навичок після опрацювання теми або розділу, сприяє об’єктивності й мінімізації суб'єктивних підходів в оцінюванні;

- мобільності, що допоможе студентові раціонально використовувати свій час.

Під час розробки та використання ЕП викладач повинен вибирати i впроваджувати нові підходи та методи навчання. Використання ЕП дає змогу переосмислити традиційні підходи до опрацювання навчального матеріалу будь-якої дисципліни. Нові підходи в навчанні студентів засобами ЕП сприяють систематичному засвоєнню знань, умінь і навичок навчальної діяльності, дозволяють підвищувати якість професійної підготовки спеціаліста, використовувати одержані знання для розв’язання будь-яких проблем.

Нові підходи, мета яких полягає в ефективності якості освіти, характеризуються використанням інтерактивних методів, які забезпечують зворотний потік інформації викладач $\Leftrightarrow$ комп'ютер $\Leftrightarrow$ студент або студент $\Leftrightarrow$ комп'ютер <=> студент незалежно від форми заняття (теоретичний матеріал, практичні завдання, самостійна робота). Інтерактивні методи навчання, які характеризуються активністю, самостійністю набутих знань під час опрацювання навчального матеріалу, частково замінюють такі традиційні методи навчання, як: демонстраційні, ілюстративнопояснювальні та інші. Але акцентуємо увагу на сполученні слів «частково замінюють», тобто впровадження нових методів навчання за допомогою комп'ютерної техніки не може повністю замінити традиційні методи навчання, потрібність яких відома ще з давніх часів. Інтерактивні методи залучають до різних видів мовленнєвої діяльності, що істотно впливає на ефективність вивчення української мови (за професійним спрямуванням). Інтерактивні методи навчання 3 
використанням електронного підручника орієнтовані на більш широку взаємодію студента з викладачем, одногрупниками з урахуванням пізнавальної і комунікативної діяльності, що спрямована не тільки на розвиток активного спілкування й аналізу будь-якого питання чи ситуації, а й на розвиток писемної комунікації (офіційноділова кореспонденція, приватне листування) засобами електронної пошти, що $є$ неодмінною вимогою при влаштуванні на роботу.

Ми переконані, що традиційні та інноваційні методи навчання повинні знаходитись у постійному взаємозв'язку і постійно доповнювати або частково замінювати один одного за необхідності.

Інтерактивні методи навчання покликані організовувати навчальну діяльність шляхом занурення студентів у процес пізнання, тобто покращити процес сприйняття навчальної інформації, який спроможний активізувати зорові і слухові центри головного мозку. Під час інтерактивного спілкування студент <=> комп’ютер <=> студент викладачеві відводиться роль помічника і контролера, який слідкує за діяльністю студентів для досягнення поставленої мети.

Протягом трьох останніх років експериментально перевірялась ефективність використання електронного підручника 3 української мови (за професійним спрямуванням) в коледжах України (м. Луганськ, м. Краснодон, м. Краматорськ, м. Глухів) з метою підвищення якості знань майбутніх спеціалістів, формування їхньої пізнавальної та комунікативної активності, розвитку власного мовлення, вільного володіння рідною мовою. У нашому експериментальному дослідженні взяли участь близько 250 студентів, які навчалися й навчаються за спеціальністю «Програмування для електронно-обчислювальної техніки та автоматизованих систем». Метою експерименту було обгрунтування доцільності застосування в навчальному процесі електронного підручника з української мови (за професійним спрямуванням), розробка методики його використання.

Під час експерименту перевірявся рівень набутих знань студентів з української мови; порівнювалася ефективність засвоєння навчального матеріалу студентами експериментальних i контрольних груп 3 дисципліни «Українська мова (за професійним спрямуванням)»; з’ясовувалась необхідність і доцільність застосування ЕП в навчальному процесі. 
Результати експерименту показали, що використання електронного підручника 3 української мови (за професійним спрямуванням) під час вивчення дисципліни «Українська мова (за професійним спрямуванням)» значно підвищує інтерес окремих студентів, тобто пізнавальну мотивацію, одну з трьох типів мотивації навчальної діяльності та забезпечує зростання ефективності засвоєння навчального матеріалу. П. Я. Гальперін акцентував увагу на тому, що пізнавальна мотивація - це «вид інтересу, найважчий для досягнення, але безцінний у тому смислі, що ніякої ціни йому не призначиш» [5, с. 197]. Ми поділяємо цю думку, бо пізнавальний інтерес є безцінною найкращою мотивацією навчальної діяльності, завдяки якій студентам цікавий сам процес навчання, жага пізнання нового, усвідомлення своєї значущості в процесі пізнання. Ми переконані, що впровадження електронного підручника 3 української мови (за професійним спрямуванням) в навчальний процес дозволить заохотити всіх студентів до цікавої творчої роботи, яка спрямована на вдосконалення набутих умінь і навичок, розвиток пізнавальної мотивації, задоволення від процесу навчання.

Ми вважаємо, що ЕП як засіб організації навчального процесу сприятиме підвищенню ефективності професійної підготовки, насамперед через інтерактивність, самостійність, мультимедійність, які $є$ необхідною умовою під час опрацювання навчального матеріалу. Структура ЕП значною мірою наближатиметься до логічного i послідовного викладу матеріалу: мета, орієнтири, зміст, шляхи розв’язання поставлених цілей, зворотний зв’язок, оцінка результатів навчальної діяльності, - що забезпечить краще сприйняття теоретичного матеріалу. Критеріями ефективності вважаємо відповідність методологічним вимогам системності, ефективності, відтворюваності, керованості як критеріям технологічності. ЕП сприятиме вирішенню проблеми індивідуалізації навчання в системі «діяльність - студент», при цьому пріоритетним є досягнення кінцевого результату.

Можливості ЕП впливають на особистісний розвиток студента, його якісну підготовку, сприяють підвищенню фахових умінь і навичок, виховують любов до рідної мови, повагу до обраної професії.

Висновки. Отже, необхідність у використанні електронного підручника як ефективного засобу підвищення якості освіти на заняттях безперечна. За допомогою ЕП студенти розвиватимуть інтуїтивне, творче, образне мислення, комунікативні 
здібності, уміння самостійно приймати рішення; удосконалюватимуть інформаційну компетентність і культуру.

Перспективи подальших пошуків у напрямку дослідження вбачаємо в розвиткові пізнавальної мотивації студентів засобами електронного підручника, удосконаленні змісту й структури ЕП, який покликаний підготувати студентів до майбутньої професійної діяльності в умовах інформаційного суспільства. Це дає підстави дійти висновку, що ЕП - ефективний засіб підвищення якості освіти.

\title{
Список використаних джерел
}

1. Гершунский Б. С. Компьютеризация в сфере образования: проблемы и перспективы / Б. С. Гершунский. - М.: Педагогика, 1987. — 264 с.

2. Вембер B. П. Роль та місце електронного підручника в навчальнометодичному комплекті 3 навчального предмета для загальноосвітньої школи // Актуальні проблеми психології: Збірник наукових праць Інституту психології ім. Г. С. Костюка АПН України / за ред. Максименка С. Д. - Т. VIII, Вип. 6. - К., 2009. - C. 43-51.

3. Виштак O. В. Критерии создания электронных учебных материалов // Педагогика. - 2003. - № 8. - С. 19-22.

4. Ястребов M. I., Полях О. О. Електронний підручник - компонент сучасного освітнього середовища // Вісник Національного технічного університету України «Київський політехнічний інститут». Серія - Радіотехніка. Радіоапаратобудування. - 2010. - Вип. 40. - С. 161-164.

5. Гальперин П. Я. Лекции по психологии: Учебное пособие для студентов вузов. - М: Книжный дом «Университет»: Высшая школа, 2002. — 400 с.

\section{ЭЛЕКТРОННЫЙ УЧЕБНИК КАК ЭФФЕКТИВНОЕ СРЕДСТВО ПОВЫШЕНИЯ КАЧЕСТВА ОБРАЗОВАНИЯ}

Шепетко Ю. Н.

\begin{abstract}
Аннотация
Актуальность материала, изложенного в статье, обусловлена потребностями в использовании информационно-коммуникационных технологий в учебном процессе, в частности электронного учебника, который призван облегчить восприятие
\end{abstract}


информации, разнообразить формы работы, заинтересовать техническими возможностями. Цель статьи состоит в доказательстве необходимости использования электронного учебника как эффективного средства повышения качества образования. Использование электронного учебника при обучении эффективно и позитивно повлияет на процесс подготовки студентов с учетом средств организации учебного процесса, структуры, методологических требований. Применение электронного учебника при обучении будет способствовать дальнейшему развитию познавательной мотивации студентов.

Ключевые слова: электронный учебник, компьютерные технологии, интерактивный метод.

\section{ELECTRONIC TEXTBOOK AS AN EFFECTIVE TOOL FOR IMPROVING THE QUALITY OF EDUCATION}

\section{Shepetko J.}

\section{Resume}

The urgency of the material stated in article, is caused by requirements for use of information and communication technologies for educational process, in particular the electronic textbook which can facilitate perception of the information, diversify work forms, interest by technical possibilities. The article aims to proof the necessity of electronic textbooks use as effective tool for improving the quality of education. Use of the electronic textbook at training will effectively and positively affect process of preparation of students taking into account the means of organization of educational process, structure, methodological requirements. Application of the electronic textbook at training will promote the further development of informative motivation of students.

Keywords: electronic textbook, computer technologies, interactive method. 